Omni-Akuatika, 15 (1): 19-29, 2019
ISSN: 1858-3873 print / 2476-9347 online
Research Article
journal homepage: http://ojs.omniakuatika.net

\title{
Length-Weight Relationship, Growth Patterns and Sex Ratio of Dog Conch Strombus canarium Linnaeus, 1758 in the Waters of Kota Batam
}

\author{
Ramses $^{{ }^{*}}{ }^{\star}$, Fauziah Syamsi ${ }^{1}$, Notowinarto ${ }^{1}$ \\ ${ }^{1}$ Biology Education Study Program, Riau Kepulauan University-Batam, Indonesia \\ ${ }^{*}$ Correspondent author: ramses.firdaus@gmail.com
}

Received 9 July 2018; Accepted 19 April 2019; Available online 10 May 2019

\begin{abstract}
This study aims to analyze the aspect length of weight relationship, growth pattern, and sex ratio of Dog conch. This research was conducted in May-August 2018. The samples were collected from three locations (stations) which became the main of catching the Dog conch in Kota Batam, namely, Jaloh Island, Kangkung Bay, and Terong Island. A total of 377 individuals (162 males and 215 females) S. canarium were collected from three research stations. The value of the length-weight relationship for females, males, dan blended, at the respective station, are Jaloh Island, $W=0,000142 \mathrm{~L}^{2,924}, R^{2}=0.555$ (female), $W=0,00049 \mathrm{~L}^{2,610}, \mathrm{R}^{2}=0.566$ (male), and $\mathrm{W}=0,000165 \mathrm{~L}^{2,881}$, with a value of $\mathrm{R}^{2}=0.572$ (blanded); Kangkung Bay, $W=0,0850 L^{1,275}, R^{2}=0.325$ (female), $0,00000511 L^{3,185}, R^{2}=0.776$ (male), and $W=0,0384 L^{1,480}$, with $R^{2}=0.374$ (blended); As well as Terong Island, $W=1,227 L^{0,746}, R^{2}=0.180$ (female), $W=0,00139 L^{2,385}, R^{2}=0.714$ (male) and $W=0,118 L^{1,305}$ with $R^{2}=0.355$ (blended). The pattern of growth of Dog conch is negative allometric $(b<3)$ where long growth is faster than weight gain, except male Dog conch in Kangkung Bay, has a coefficient $(b>3)$ has a positive allometric growth pattern, where weight gain is faster than long increments. The sex ratio of Dog conch on Jaloh Island and Terong Island is balanced, while in Kangkung Bay it is not balanced. Overall the sex ratio in the study location is not balanced with a ratio of 1: 1.33 with the expectation frequency (Ei) of 188.8.
\end{abstract}

Keywords: Strombus canarium, length-weight, growth pattern, sex ratio.

\section{Introduction}

The importance of mollusk biota for human life including Gastropoda has been started since the past. This was revealed in several researchers' reports on Archaeozoological studies (Ktalav \& Borowski, 2010; Will, Kandel, Kyriacou, \& Conard, 2016; Hood \& Melsæther, 2016). However, currently, there are not many known species of bioecological important species, including species of Strombus canarium. Cob, et al. (2012) explain the ecology of Strombus canarium is still poorly understood and is largely unexplained. Although the life of the Dog conch is closely related to the existence of seagrass ecosystems, certain distributions, and preferences in habitats that are not widely known. This is due to the lack of research on this species. Determining mechanisms that regulate distribution and abundance is very important for species management. The status of the sustainability of the Gonggong snail population in the ecological dimension can be seen from the four measured variables, namely the condition of the waters, substrate, capture technology and size of capture (Khodijah \& Anggraini, 2015).

Dog conch, Strombus canarium Linnaeus 1758 (Gastropod: Strombidae) are marine biota inhabiting intertidal ecosystems on muddy substrates overgrown with seagrass vegetation, which have an important role in the food chain cycle, as well as an indicator of monitoring water quality. Suratissa \& Rathnayake, (2017) report that ecologically gastropods act as herbivores, carnivores, carcasses, ciliary feeders, and parasites in the food chain of the marine ecosystem. Generally, gastropods belong to two trophic levels in the seafood chain, as trophic level two and third level.

Dog conch is native to the Indo-Pacific waters that are spread in the waters of India-Sri Lanka, South Japan, northern Australia, and Indonesia. In Indonesia, Dog conch are reported to be found in the waters of Lingga, Riau Islands (BP-PSPL UNRI, 2010); Bangka Belitung Islands (Dody, 2011; Utami, 2012). Dog conch in the Riau Islands is typical biota that lives on the coast of Bintan Island and its 
surroundings (Viruly, 2011). This biota became a superior fishery commodity which became an icon of seafood culinary in Riau Islands Province, especially Batam City. Dependence on natural stocks and overfishing will threaten the sustainability (quantity and quality) of the Dog conch in Batam waters. The success of the development of Dog conch cultivation in the future will be able to answer the problem of the high demand for Dog conch without depending on its population in nature and can increase the income of fishing communities. While on the other hand, information about the diversity and bioecology of Dog conch is unknown. This study aims to analyze aspects of biology such as the length-weight relationship, the pattern of growth, and sex ratio Dog conch Canarium Strombus in the association of the City of Batam, Riau-Indonesian Islands.

\section{Material and Methods}

Dog conch (Strombus canarium) sampling was conducted in three locations (stations) which became the center of catching the Dog conch that is in Jaloh Island, Kangkung Bay and Terong Island, Belakang Padang Districts, Kota Batam. This research was conducted in May-August 2018. Sampling in this study follows the linetransect method which is placed randomly at 3 observation points at each station. The transect is made as long as 10 meters parallel to the coastline with an observation distance of one (1) meter on the left and one (1) meter on the right so that the area observed per transect is $2 \mathrm{~m} \times 10 \mathrm{~m}$ or $=20$ meters $^{2}$. Thus the area of observation in each station is $3 \times 20 \mathrm{~m}^{2}$ or $=60 \mathrm{~m}^{2}$.

\section{Morphometric measurements}

The morphometric measurements of Dog conch were performed on Shell Length (SL), Body Whorl Length (BW), Shell Width (SW), Sheel Depth (SD), Outer Lip / Lip thickness $(\mathrm{OL})$ and Aperture length (AL) and weight (W) (Figure 2). For the size of the weight carried out weighing the wet weight. To measure Dog conch morphometry, use the calipers and digital scales.

\section{Length-weight relationship and pattern of growth}

Length-Weight relationships described in two forms, namely isometric and allometric, with the equation:

$$
\begin{aligned}
& \text { Remarks: } \quad W=a L^{b} \\
& W=\text { weight of the Dog conch }(g) \\
& L=\text { length of Dog conch shell }(\mathrm{mm}) \\
& a \text { and } b=\text { Constants }
\end{aligned}
$$

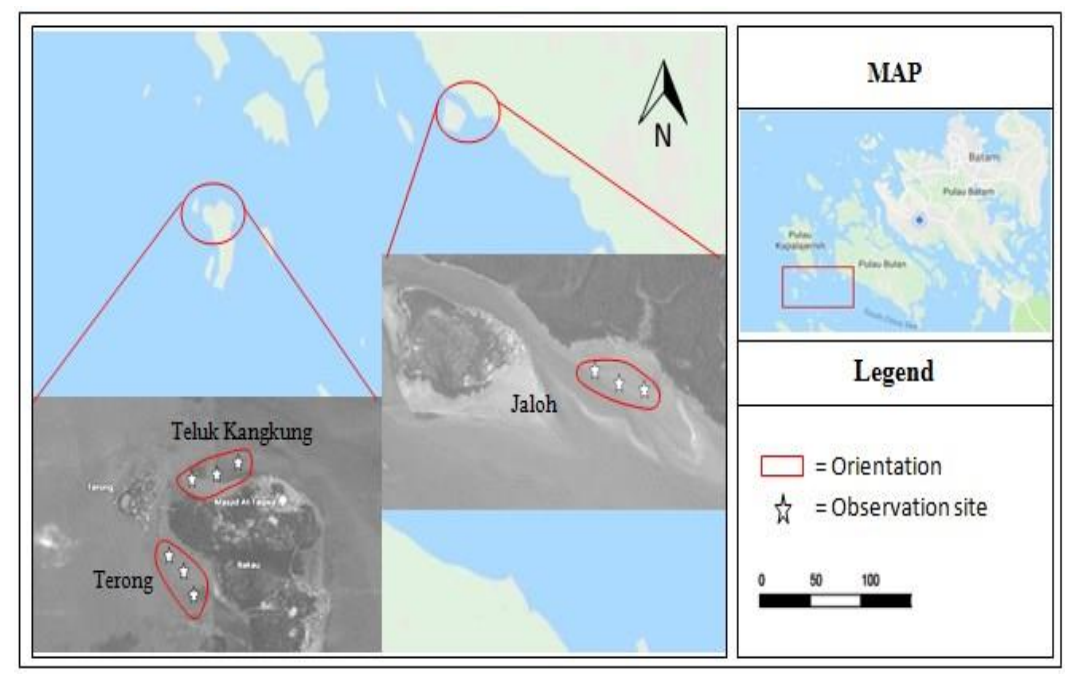

Figure 1. Research site 
If linear through logarithmic transformation, the equation: $\log W=\log a+$ b Log L. Obtains parameters a and b, using simple linear regression analysis with Log $W$ as ' $y$ ' (non-independent variable) and Log $L$ as ' $x$ ' (independent variable) carried out by the $t$ test. Draw conclusions as follows:

$b=3$, the length and weight relationship is isometric.

$b \neq 3$, the relationship between length and weight is allometric

Isometric means a long increase in balance with increasing weight. Positive allometric, if $b \geq 3$ (weight gain faster than length increment) and negative allometric, if $b$ $<3$ (length increase is faster than added weight).

$$
t_{\text {hitung }}=\frac{b_{1}-b_{0}}{s b_{1}}
$$

Remarks:

$\mathrm{b}_{1}=$ Value $\mathrm{b}$ (length-weight relationships)

$\mathrm{b}_{0}=3$

$\mathrm{Sb}_{1}=$ Deviation of coefficient $\mathrm{b}$

Furthermore, the count is compared with the t-value at the $95 \%$ confidence interval. Then to find out the pattern of growth, the decision rules taken refer to Nasoetion \& Barizi (1980).

\section{Sex ratio}

Dog conch sex is determined by making direct observations of the Dog conch genitals. Determination of Dog conch genitals refers to Dody, (2012). After morphometric measurements, each individual is separated from the frame so that he can observe his dark instrument. Analysis of knowing the balance of the sex ratio of male and female fish, namely:

$$
\mathrm{X}=\frac{\mathrm{J}}{\mathrm{B}}
$$

Remarks:

$X=$ Sex ratio

$\mathrm{J}=$ Number of male fish (tail)

$B=$ Number of female fish (tail)

The relationship between male and female from a population studied can be determined by conducting sex ratio analysis using the chi-square test $\left(X^{2}\right)$ (Walpole, 1993).

$$
X^{2}=\frac{0 i-e^{2}}{e i}
$$

Remarks:

$X^{2}=$ Value for random variables whose distribution of drawings approaches the distribution of chi square.

$\mathrm{oi}=$ The number of male and female bark frequencies observed in the i data

ei $=$ Number of expectation frequencies from male and female barks in the i data

Furthermore, the calculated $X^{2}$ value is compared with the $X^{2}$ table value at the $95 \%$ confidence interval. Then to find out the sex ratio, the rules of decision are taken referring (Walpole, 1993).

\section{Results and Discussion}

Overall the number of S.canarium in Jaloh Island waters was 215 individuals, consisting of 109 female individuals and 106 male individuals. There are 78 individuals in Kangkung Bay waters, consisting of 57 female individuals and 21 male individuals. While in the Terong Island waters, there were 84 individuals, consisting of 49 female individuals and 35 male individuals.

\section{Jaloh Island}

The average length of the Dog conch on Jaloh Island is $64.29 \mathrm{~mm}$, with a range of 48.35-78.82 $\mathrm{mm}$. The relationship of the length of the combined weight (male and female) of the bark snail as a whole has a linear regression equation $\mathrm{Y}=2.881 \mathrm{x}-8.711(\mathrm{~W}=$ 0,000165 L2,881) with a value of $R^{2}=0.572$, females having the equation $Y=2.924 x-8,858$ $(W=0,000142 \mathrm{~L} 2,924)$ with a value of $R^{2}=$ 0.555 , and males having the equation $Y=$ $2.610 \mathrm{x}-7.622(\mathrm{~W}=0,00049 \mathrm{~L} 2,610)$ with $\mathrm{a}$ value of $R^{2}=0.566$. The overall growth pattern of Dog conch in Jaloh Island waters as a whole has a coefficient of $b=2,881$, females have a coefficient value of $b=2,924$ and males have $a$ coefficient value of $b=2,610$ which indicates that Dog conch have negative allometric growth patterns, tend to be elongated namely length increase faster than weight gain (Table 1). 

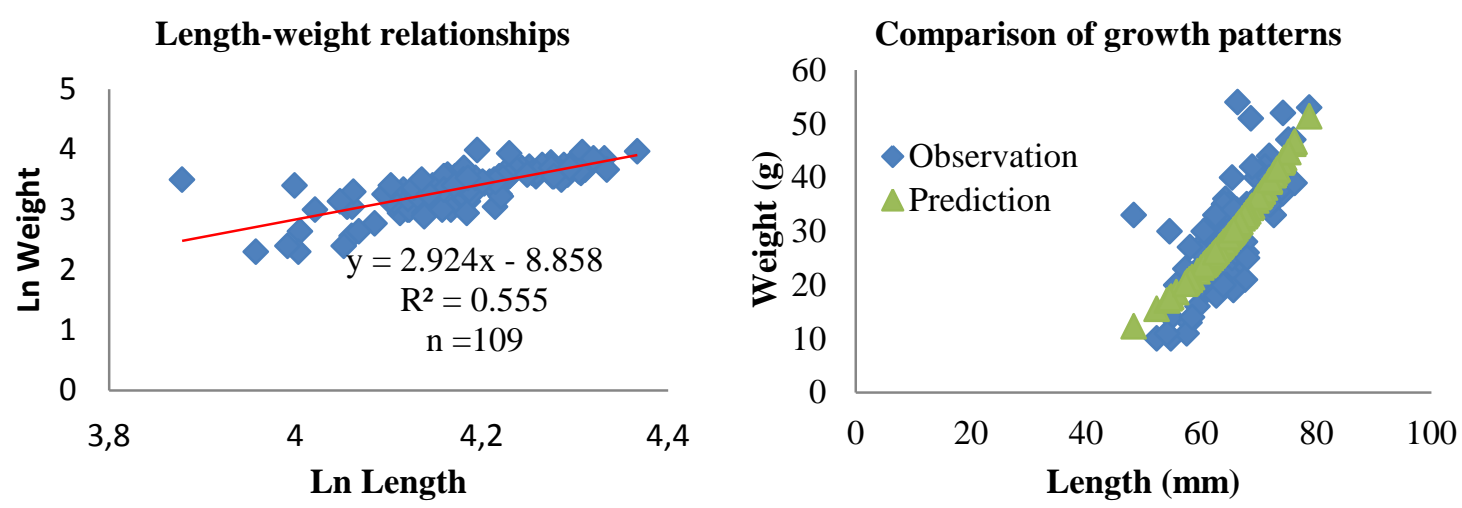

(a)
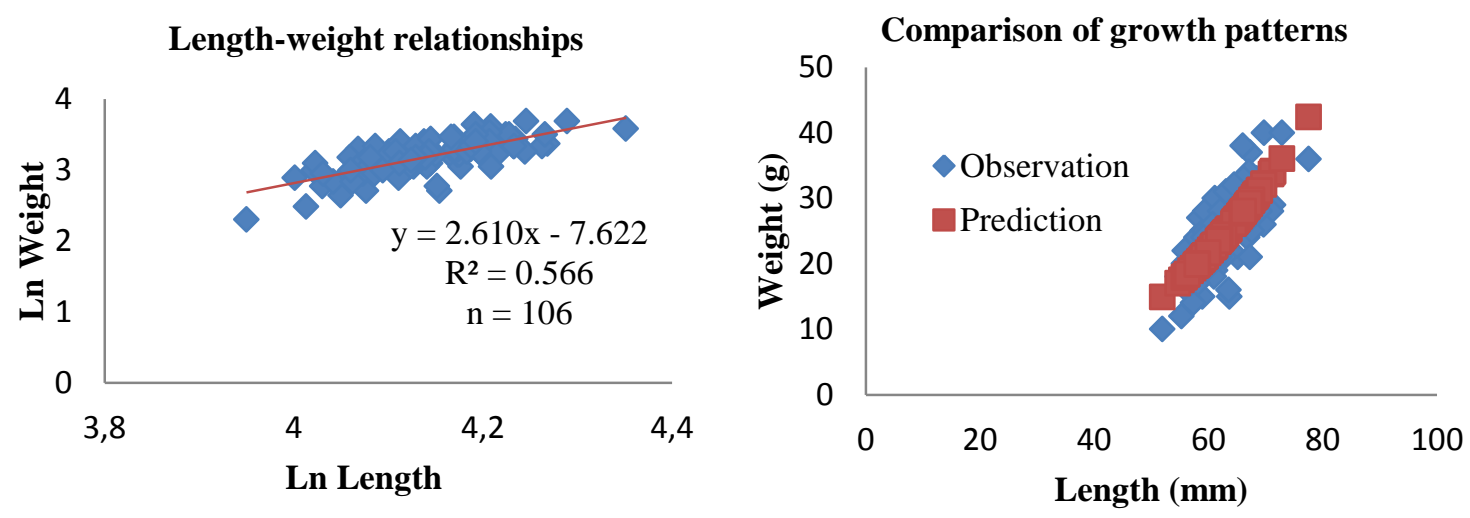

(b)
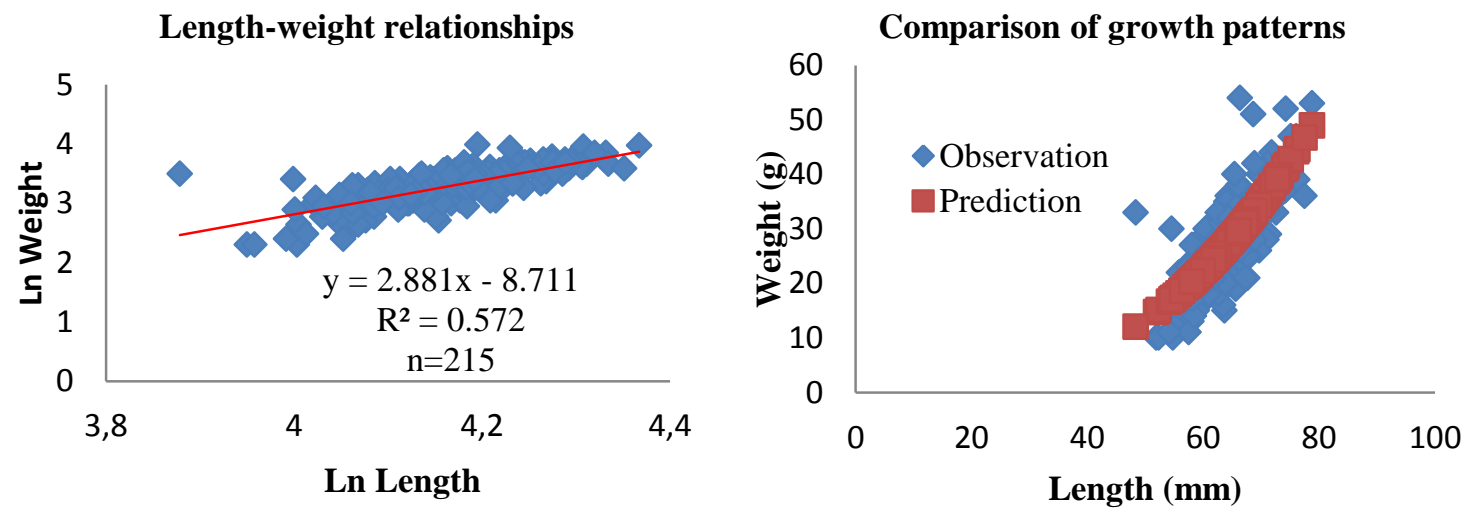

(c)

Figure 2. Length-weight relationships and comparison of growth patterns that are measured (observations) and predicted the Dog conch (S.canarium) in Jaloh Island waters: (a) Female, (b) Male, (c) Combined.

Table 1. The results of the calculation of the length-weight relationships of the Dog conch ( $S$. canarium) in Jaloh Island waters

\begin{tabular}{lccccccc}
\hline Sex & $\mathbf{N}$ & $\mathbf{a}$ & $\mathbf{b}$ & $\mathbf{R}^{2}$ & $\mathbf{t}-$ test & $\begin{array}{c}\mathbf{t}-\text { table } \\
\mathbf{( \alpha = 0 , 0 5 )}\end{array}$ & \multicolumn{1}{c}{ Growth Pattern } \\
\hline $\mathrm{F}$ & 109 & 0.000142 & 2,924 & 0,555 & 11,894 & 1.65909 & $\begin{array}{l}\text { Negative allometrics, tend } \\
\text { to be elongated }\end{array}$ \\
$\mathrm{M}$ & 106 & 0.00049 & 2,610 & 0,566 & 11,600 & 1.65950 & $\begin{array}{l}\text { Negative allometrics, tend } \\
\text { to be elongated }\end{array}$ \\
$\mathrm{Gb}$ & 215 & 0.000165 & 2.881 & 0,572 & 16,989 & 1.65251 & $\begin{array}{l}\text { Negative allometrics, tend } \\
\text { to be elongated }\end{array}$ \\
\hline
\end{tabular}

Remarks: $\mathrm{F}=$ Famale, $\mathrm{M}=$ Male, $\mathrm{Gb}=$ Combined 


\section{Kangkung Bay}

The relationship of the combined weight length (male and female) of the Dog conch has a linear regression equation $Y=$ $1.480 x-3.259\left(\mathrm{~W}=0.0384 \mathrm{~L}^{1.480}\right)$ with a value of $\mathrm{R}^{2}=0.374$, the female has the equation $\mathrm{Y}=$ $1.275 \mathrm{x}-2.465\left(\mathrm{~W}=0,0850 \mathrm{~L}^{1,275}\right)$ with a value of $R^{2}=0.325$, and males have the equation $Y=$ $3.185 x-9,881\left(0.00000511 L^{3,185}\right)$ with a value of $R^{2}=0.776$. The overall growth pattern of the
Dog conch S.canarium in the waters of Kangkung Bay has a coefficient of $b=1,480$, females have a coefficient value of $b=1,275$ which indicates that the Dog conch has a negative allometric growth pattern, which tends to elongate, which is faster than weight gain. Whereas male snails have a coefficient value of $\mathrm{b}=3.185$ having a positive allometric growth pattern, where the weight gain is faster than the length increase (Table 2).

\section{Length-weight relationships}

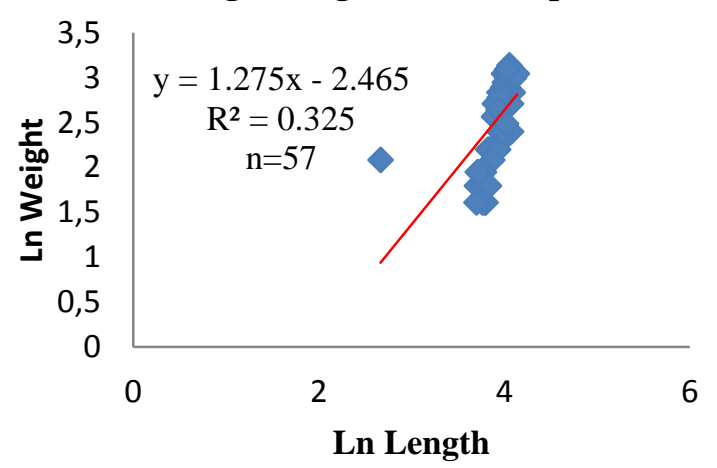

\section{Comparison of growth patterns}

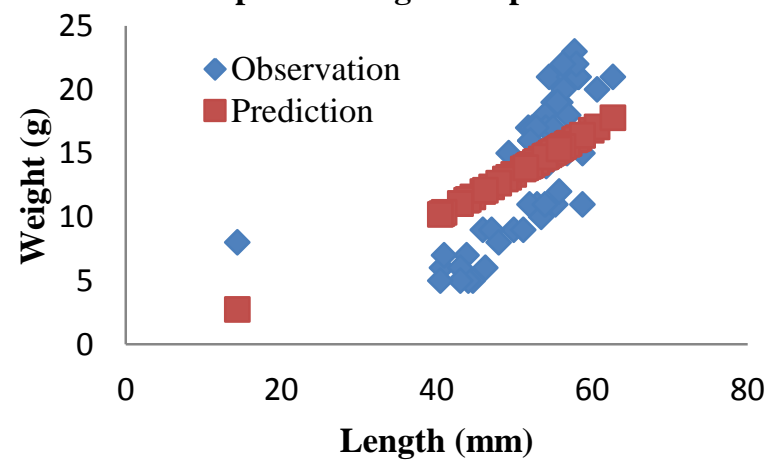

(a)

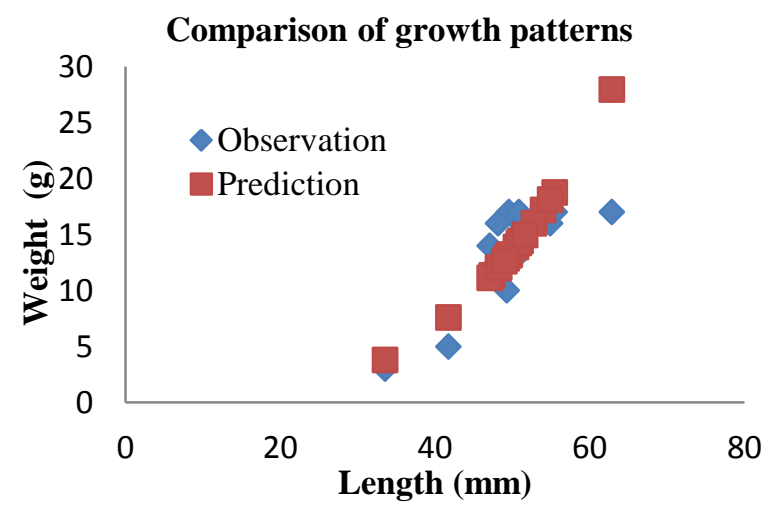

(b)

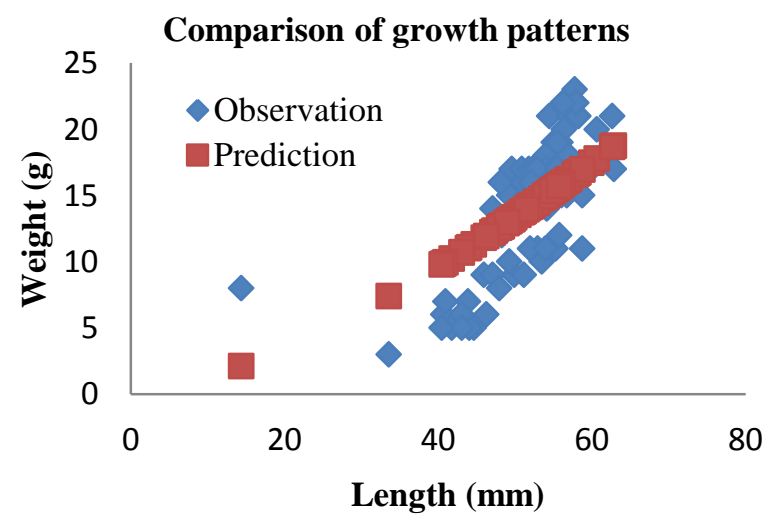

(c)

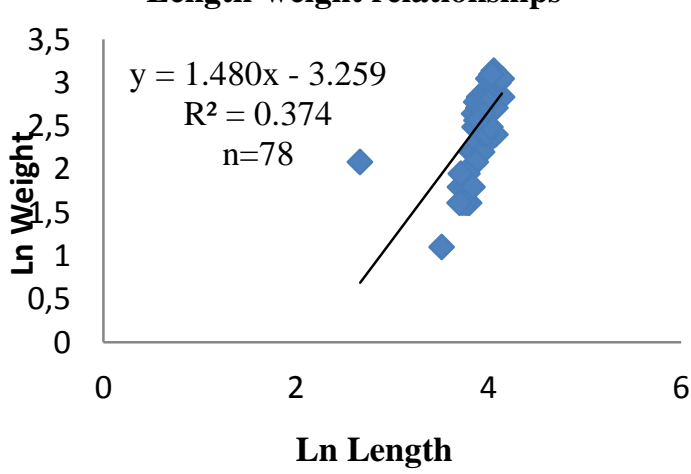

Figure 3. Length-weight relationships and comparison of growth patterns that are measured (observations) and predicted the Dog conch (S.canarium) in Kangkung Bay waters: (a) Female, (b) Male, (c) Combined. 
Table 2. The results of the calculation of the length-weight relationships of the Dog conch ( $S$. canarium) in Kangkung Bay waters

\begin{tabular}{|c|c|c|c|c|c|c|c|}
\hline Sex & $\mathbf{N}$ & a & b & $\mathbf{R}^{2}$ & t- test & $\begin{array}{c}\text { t- table } \\
(\alpha=0,05)\end{array}$ & Growth Pattern \\
\hline $\mathrm{F}$ & 57 & 0.0850 & 1.275 & 0.325 & 7,088 & 1.67252 & $\begin{array}{l}\text { Negative allometric, tend } \\
\text { to be elongated }\end{array}$ \\
\hline$M$ & 21 & 5.11371E-05 & 3.185 & 0776 & 6,586 & 1.72472 & Positive allometric \\
\hline $\mathrm{Gb}$ & 78 & 0.0384 & 1.480 & 0.374 & 8,849 & 1.66462 & $\begin{array}{l}\text { Negative allometric, tend } \\
\text { to be elongated }\end{array}$ \\
\hline
\end{tabular}

Remarks: $\mathrm{F}=$ Famale, $\mathrm{M}=$ Male, $\mathrm{Gb}=$ Combined

\section{Terong Island}

The relationship of the combined weight length (male and female) of the Dog Conch has a linear regression equation $Y=1,305 x-2,135$ $\left(\mathrm{W}=0,118 \mathrm{~L}^{1,305}\right)$ with a value of $\mathrm{R}^{2}=0.355$, the female has the equation $Y=0.746 \times 0.205(\mathrm{~W}=$ $1,227 \mathrm{~L}^{0746}$ ) with the value of $R^{2}=0.180$, and males have the equation $\mathrm{Y}=2.385 \mathrm{x}-6.577(\mathrm{~W}=$ $0.00139 L^{2,385}$ ) with a value of $R^{2}=0.714$. The overall growth pattern of the Dog ConchS.canarium in Terong Island waters has a coefficient $b=1,305$, females have $a$ coefficient value $b=0,746$ and males have a coefficient value $b=2,385$ which indicates that the Dog Conch has a negative allometric growth pattern, tends to elongate namely length increase faster than weight gain (Table 3).

The growth pattern of the Dog conch at the location of this study follows the growth pattern of Gonggong Snails in general. In all locations and sex, the pattern of Dog conch growth is negative allometric or length increase is faster than weight gain, except male gong in Kangkung Bay has a positive allometric growth pattern. This condition according to (Yulianda, 2007 cited in Utami, 2012) is caused when reaching the maximum shell length growth of the Dog conch, the energy used is more towards reproduction, where the development of gonads is not followed by weight gain. The development of gonads can also affect the value of $b$, however, the value of $b$ is largely influenced by food availability and environmental conditions such as temperature, $\mathrm{pH}$ and oxygen (Muchlisin, et al., 2010). The difference in the value of $b$ indicates that the type of organism and the condition of the location is one that affects the pattern of growth of the organism (Zabarun, 2016).

When viewed from the coefficient of determination $\left(R^{2}\right)$ in Jaloh Island waters, the $R^{2}$ value of a female is 0.555 , Male 0.566 and combined (male and female) is 0.572 which indicates that only $55 \%-57 \%$ of the weight is affected by the presence of long increments. While $43 \%$ is influenced by other unknown factors. In other locations in Kangkung Bay, $\mathrm{R}^{2}$ values were female 0.325 , males 0.776 , and combined 0.374. Whereas in Terong Island waters the value of $R^{2}$ was female 0.180 , male 0.714 , and combined 0.355 . Overall, from this study, the $R^{2}$ value indicates the low effect of adding length to weight addition. However, another opinion says that this condition indicates that the environment where the Dog conch (S.canarium) lives is not supportive (experiencing environmental degradation) because the pattern of growth depends on food availability (Siddik, 2011). Positive allometry indicates biota adapting better to the environment (Ramadhani et al., 2017).

Table 3. The results of the calculation of the length-weight relationships of the Dog conch ( $S$. canarium) in Terong Island waters

\begin{tabular}{llllllll}
\hline Sex & $\mathbf{n}$ & $\mathbf{a}$ & $\mathbf{b}$ & $\mathbf{R}^{2}$ & $\mathbf{t}$ - test & $\mathbf{t}$ - table & Growth pattern \\
\hline $\mathrm{F}$ & 49 & 1.2275 & 0.746 & 0.180 & 4.157 & 1.67722 & Negative allometric, tend to be elongated \\
$\mathrm{M}$ & 35 & 0.0014 & 2.385 & 0.714 & 8.725 & 1.68957 & Negative allometric, tend to be elongated \\
$\mathrm{Gb}$ & 84 & 0.1183 & 1.305 & 0.355 & 7.941 & 1.66320 & Negative allometric, tend to be elongated \\
\hline
\end{tabular}

Remarks: $\mathrm{F}=$ Famale, $\mathrm{M}=$ Male, $\mathrm{Gb}=$ Combined 

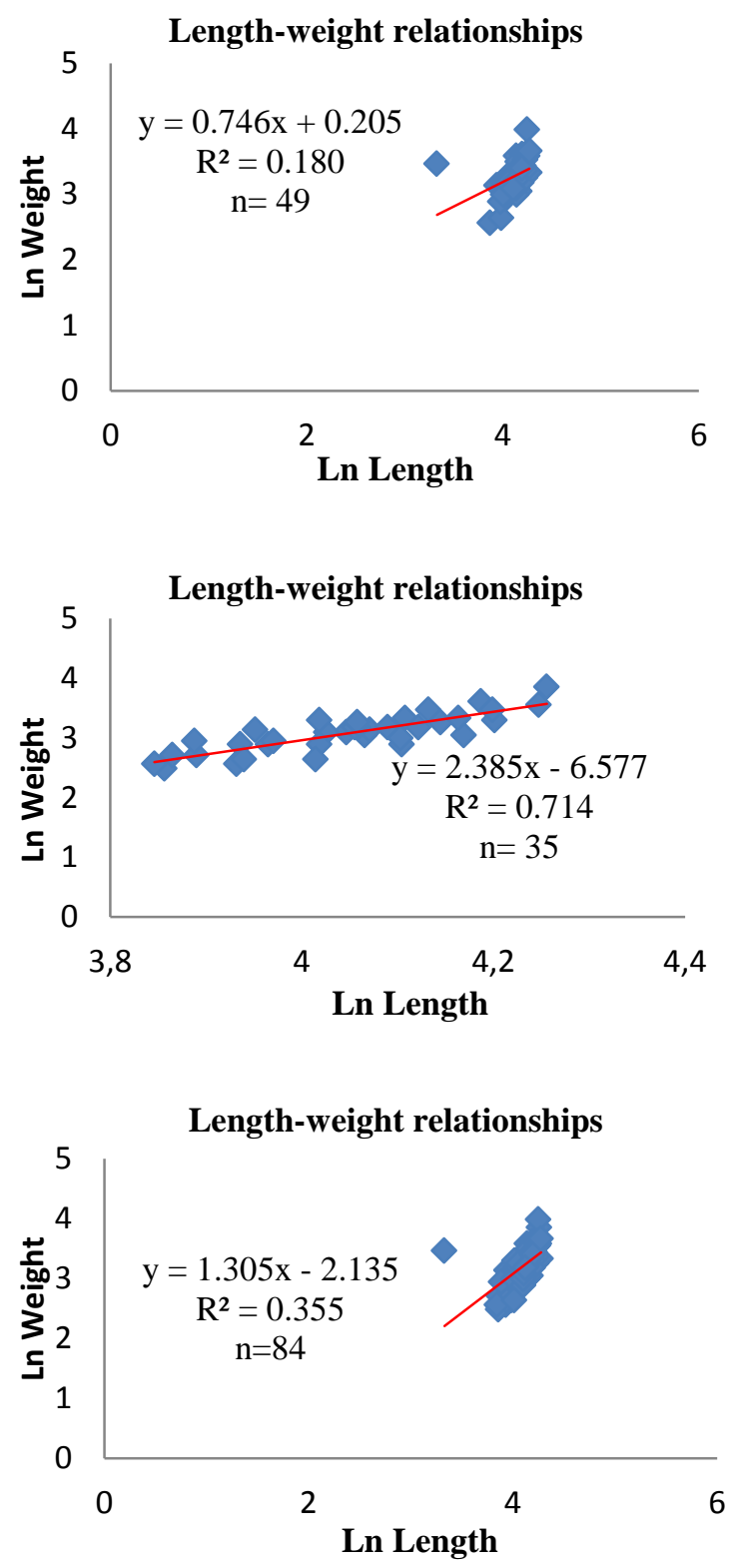

(c)

Figure 4. Length-weight relationships and comparison of growth patterns that are measured (observations) and predicted the Dog conch (S.canarium) in Terong Island waters: (a) Female, (b) Male, (c) Combined.

In relation to the condition of the aquatic environment, when viewed from the factor value (Wr) in this study, it shows values above 100 (101-107) for all locations and genders. The value of the condition factor (Wr) which is 100 or more can reflect that there is a balance between food availability relative to the presence of predators. The condition factor value also shows that water quality is still sufficient to support fish communities. (Muchlisin, et al., 2010). In addition to the availability of feed and predators, various biotic, abiotic, and fisheries management factors also influence various conditions (Murphy et al.,

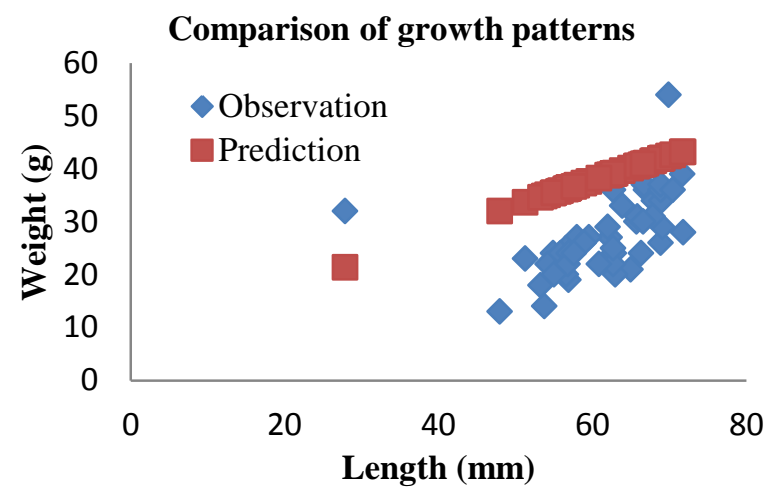

(a)

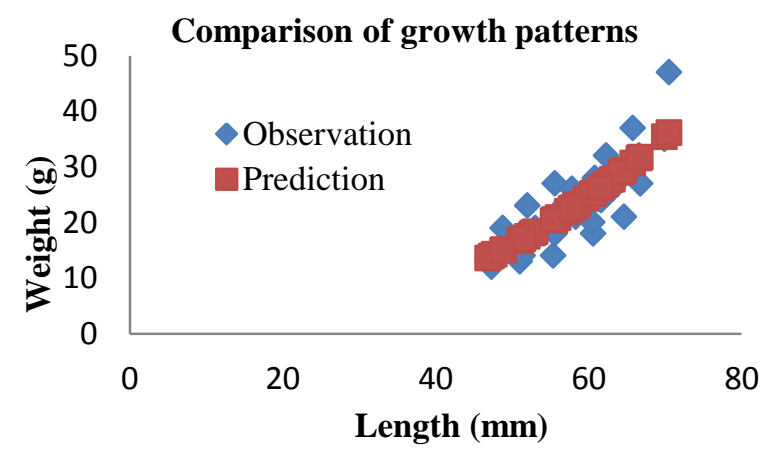

(b)

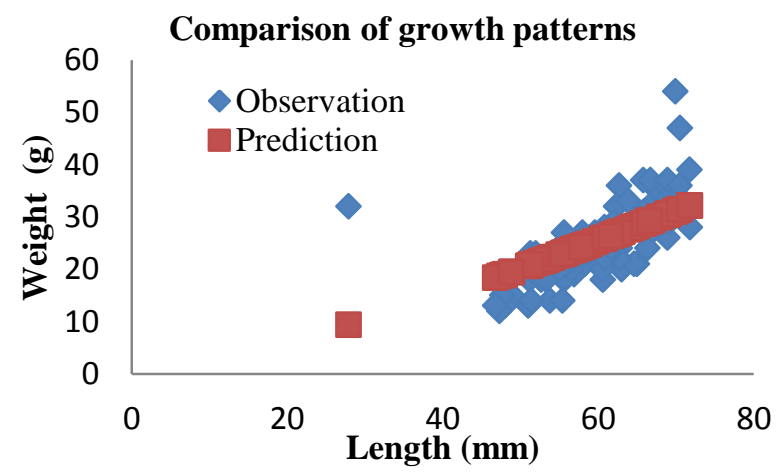




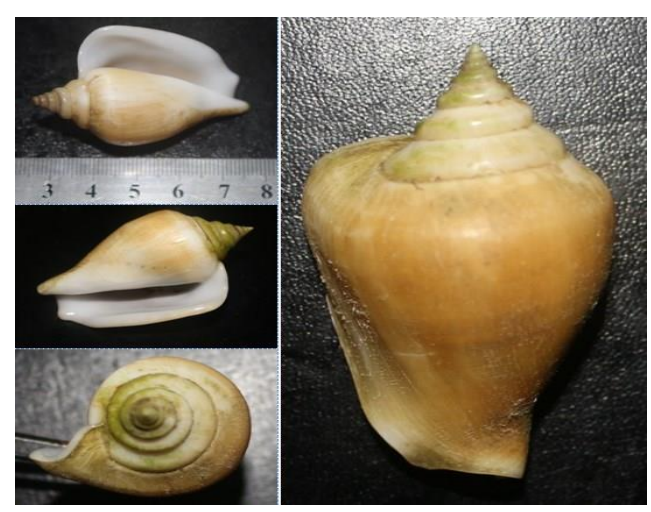

Figure 5. Dog conch (Strombus canarium)

Sex ratio

Sex ratio is the ratio of male and female in a population. The overall composition of the Dog conch on Jaloh Island was 215 individuals of the S.canarium, 109 female individuals and 106 male individuals. Meanwhile, in Kangkung Bay, there is 78 Dog conchin total, 57 female individuals and 21 male individuals. Terong island has a total composition of 84 individuals, 49 female individuals, and 35 male individuals. The overall results of the S.canarium from three locations were 377 individuals, 215 individual females and 162 male individuals.

Table 4. The results of the analysis of the Dog conch sex ratio

\begin{tabular}{lcccccccl}
\hline \multirow{2}{*}{ Stasiun } & \multicolumn{2}{c}{ Sex } & $\begin{array}{c}\text { Total } \\
\text { Indv. }\end{array}$ & $\begin{array}{c}\text { Expectation } \\
\text { Frequency } \\
\text { (Ei) }\end{array}$ & $\begin{array}{c}\text { Ratio } \\
\text { (M/F) }\end{array}$ & $\begin{array}{c}\text { Chi } \\
\text { Square } \\
\mathbf{X 2}\end{array}$ & $\begin{array}{c}\mathbf{X 2} \\
\mathbf{( 0 . 0 5 )} \\
\mathbf{V = 1}\end{array}$ & Inference \\
\hline Jaloh & 106 & 109 & 215 & 108 & 1.03 & 0.042 & 3.841 & balanced \\
Kangkung & 21 & 57 & 78 & 39 & 2.71 & 16.615 & 3.841 & Not balanced \\
Terong & 35 & 49 & 84 & 42 & 1.40 & 2.333 & 3.841 & balanced \\
Combined & 162 & 215 & 377 & 188.5 & 1.33 & 7.451 & 3.841 & Not balanced \\
\hline
\end{tabular}

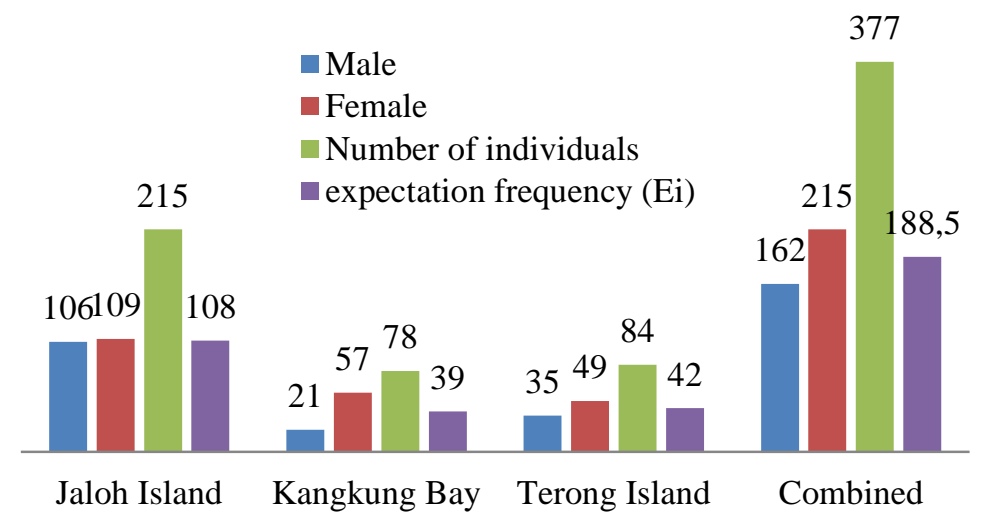

Figure 6. Sex Ratio S.canarium

Determination of sex ratio using the chisquare test is intended to determine the sex ratio of male and female balanced or unbalanced. In the locations of Jaloh Island and Terong Island, the sex ratio between male and female snails is ideal or balanced. While in
Kangkung Bay the ratio of the male and female sex is not balanced. In a combined calculation at three locations, the population of males and females is not balanced. The ideal condition of the sex ratio of snails can support the spawning process optimally in nature so that it can 
increase the Dog conch population. Dog conch are dioecious organisms, which are organisms, each of which is clearly visible between males and females. The Dog conch spawning season runs from late November to early March. Sexually affirmed the Dog conch occurs in the early times during the ontogeny species. Male Dog conch reach an initial maturity level shorter in size than female snails (Dody, 2008).

\section{Conclusion}

The pattern of growth of Dog conch $S$. canarium is negative allometric $(b<3)$ where long growth is faster than weight gain, except male Dog conch in Kangkung Bay, has a coefficient ( $b>3$ ) has a positive allometric growth pattern, where weight gain is faster than long increments. The sex ratio of Dog conch on Jaloh Island and Terong Island is balanced, while in Kangkung Bay it is not balanced. Overall the sex ratio in the study location is not balanced with a ratio of $1: 1.33$ with the expectation frequency (Ei) of 188.8 .

\section{Acknowledgment}

Further thanks to the Ministry of Research and Higher Education, which has funded this research through Hibah PDP with Contract 04/KP-PDP/LPPM/UNRIKA/IV/2018.

\section{References}

BPP-PSPL-UNRI. 2010. Studi Distribusi Dan Eksploitas Siput Gonggong Di Lokasi Coremap II Kabupaten Lingga. Universitas Riau, Pekanbaru.

Cob, Z.C. 2008. Biology and Ecology of Dog Conch (Strombus canarium Linnaeus, 1758) (Gastropoda: Strombidae) from Merambong Shoal, Johor Straits, Malaysia.PhD Thesis, Universiti Putra Malaysia. 377pp

Cob, Z. C., Arshad, A., Ghaffar, M. A., Bujang, J. S., Muda, W. L. W. 2009. Development and Growth of Larvae of the Dog Conch, Strombus canarium (Mollusca: Gastropoda), in the Laboratory. Zoological Studies, 48(1), 1-11.

Cob, Z. C., Arshad, A., Bujang, J. S., Bakar, Y., Simon, K. D., Mazlan, A. G. 2012. Habitat preference and usage of Strombus canarium Linnaeus, 1758Gastropoda: Strombidae) in Malaysian seagrass beds. Italian Journal of Zoology, 79(3), 459-467.

Cob, Z. C., Arshad, A., Bujang, J. S., Muda, W. L. W., Ghaffar, M. A. 2010. Metamorphosis Induction of the Dog
Conch Strombus canarium (Gastropoda: Strombidae) Using Cues Associated with Conch Nursery Habitat. Journal of Applied Sciences, 10(8), 628-635.

Cob, Z. C., Arshad, A., Bujang, J. S., Ghaffar, M. A. 2008a. Sexual Maturity and Sex Determination in Strombus canarium Linnaeus, $1758 \quad$ (Gastropoda: Strombidae). Journal of Biological Sciences, 8(3), 616-621.

Cob, Z. C., Arshad, A., Idris, M. H., Bujang, J. S., Ghaffar, M. A. 2008b. Sexual Polymorphism in a Population of Strombus canarium Linnaeus, 1758 (Molusca: Gastropoda) at Merambong Shoal, Malaysia. Zoological Studies, 47(3), 318-325.

Cob, Z. C., Arshad, A., Bujang, J. S., Ghaffar, M. A. 2009. Species Description and Distribution of Strombus ( Mollusca: Strombidae ) in Johor Straits and its Surrounding Areas. Sains Malaysiana, 38(1), 39-46.

Daeng, B. 2018. Keterkaitan Jenis dan Kerapatan Lamun dengan Tesktur di Dusun Biringkassi Desa Sapanang Kecamatan Binamu Kabupaten Jeneponto. Skripsi. Universitas Hasanuddin, Makassar.

Dody, S. 2007. Habitat dan sebaran spasial Siput Gonggong (Strombus turturella) di Teluk Klabat, Bangka Belitung. In Prosiding Seminar Nasional Moluska dalam Penelitian, Konservasi dan Ekonomi. Jakarta: Pusat Penelitian Oseanografi LIPI, p. 100.

Dody, S. 2012. Pemijahan dan perkembangan larva siput gonggong (Strombus turturella). Jurnal IImu dan Teknologi Kelautan Tropis, 4(1), 107-113.

Dody, S. 2011. Pola Sebaran, Kondisi Habitat dan Pemanfaatan Siput Gonggong (Strombus turturella) $\mathrm{Di}$ Kepulauan Bangka Belitung. Oseanologi dan Limnologi di Indonesia, 37(2), 339-353.

Dwiyitno, Aji, N., Indriati, N. 2018. Heavy metal residue in fish and environmental quality of Barito River, South Kalimantan Province. Jurnal Pascapanen dan Bioteknologi Kelautan dan Prikanan, 3(2), 147-155.

Effendi, H. 2003. Telaah kualitas air Bagi Pengelolaan Sumber Daya dan Lingkungan Perairan. Kanisius, Yogyakarta.

English, S., Wilkinson, C., Baker, Y. 1997. Survey Manual for Tropical Marine Resources (2nd Edition). Australian 
Institute of Marine Scienc, p.378.

Feryatun, F., Hendrarto, B., Widyorini, N. 2012. Kerapatan dan distribusi lamun seagrass berdasarkan zona kegiatan yang berbeda di perairan pulau pramuka, kepulauan seribu. Journal og Management of Aquatic Resources,1-7.

Gosari, B.A.J., Haris, A. 2012. Studi Kerapatan dan Penutupan Jenis Lamun Di Kepulauan Spermonde. Torani (Jurnal IImu Kelautan dan Perikanan), 22(3), 156-162.

Hood, B. C., Melsæther, S. G. 2016. Shellfish exploitation in Stone Age Arctic Norway: procurement patterns and household activities. Acta Borealia, 33(1), 1-29. https://doi.org/10.1080/

08003831.2016 .1154673

Ismarti, I., Ramses, R., Suheryanto, S., Amelia, F. 2017. Heavy Metals $(\mathrm{Cu}, \mathrm{Pb}$ and $\mathrm{Cd})$ in Water and Angel Fish (Chelmon rostractus) from Batam Coastal, Indonesia. Omni-Akuatika, 13(1), 78-84.

Khodijah., Anggraini, S.F. 2015. Keberlanjutan Populasi Siput Gonggong (Strombus canarium). Jurnal Mitra Bahari, 9(1), 3742.

Kiswara, W., Hutomo, M.1985. Habitat dan Sebaran Geografik Lamun. Oseana, $\mathrm{X}(1), 21-30$.

Ktalav, I., Borowski, O. 2010. Molluscs from Iron Age Tel Halif. Tel Aviv: Journal of the Institute of Archaeology of Tel Aviv University, 37(1993), 126-135. https://doi.org/10.1179/033443510x1263 2070179342

Lanuru, M. 2011. Bottom Sediment Characteristics Affecting the Success of Seagrass (Enhalus acoroides) Transplantation in the Westcoast of South Sulawesi (Indonesia). International Conference on Chemical, Biological and Environmental Engineering, 20(2011), 97-102.

Latiolais, J. M., Taylor, M. S., Roy, K., Hellberg, M. E. 2006. A molecular phylogenetic analysis of strombid gastropod morphological diversity. Molecular Phylogenetics and Evolution, 41(2006), 436-444.

Muchlisin, Z. A., Musman, M. and Azizah, M. N. S. 2010. Length-weight relationships and condition factors of two threatened fishes, Rasbora tawarensis and Poropuntius tawarensis, endemic to Lake Laut Tawar, Aceh Province, Indonesia. J. Appl. Ichthyol. 26 (2010), 949-953. doi: 10.1111/j.1439-0426.2010.01524.x
Nontji, A. 2002. Laut Nusantara, PT Djambatan. Jakarta.

Novriadi, R. 2011. Laporan Kualitas Air Pada Instalasi Budidaya Ikan Laut Bulan Maret Tahun 2011, Batam: Pengendali Hama Dan Penyakit Ikan Balai Budidaya Laut.

Nybakken, J.W. 1992. Biologi laut: Suatu pendekatan ekologi, Jakarta: PT Gramedia.

Nybakken, J.W. 1988. Biologi Laut: Suatu Pendekatan Ekologis. M. Eidman et al., eds., PT Gramedia. Jakarta.

Putra, I.P. 2014. Kajian Kerapatan Lamun Terhadap Kepadatan Siput Gonggong (Strombus Canarium) Di Perairan Pulau Penyengat Kepulauan Riau. Skripsi. UMRAH, Tanjung Pinang.

Ramadhani, A., Muchlisin, Z.A., Sarong, M.A., Batubara, A.A. 2017. Hubungan panjang berat dan faktor kondisi ikan kerapu Famili Serranidae yang tertangkap di Perairan Pulo Aceh Kabupaten Aceh Besar, Provinsi Aceh. Depik. Volume 6, (2): 112-121. DOI: 10.13170/depik.6.2.7017

Siddik, J. 2011. Sebaran Spasial dan Potensi Reproduksi Populasi Siput Gonggong (Strombus turturela) di Teluk Klabat Bangka-Belitung. Skrispi. Institut Pertanian Bogor.

Suratissa D. M., U. Rathnayake, "Effect of pollution on diversity of marine gastropods and its role in trophic structure at Nasese Shore, Suva, Fiji Islands," J. Asia-Pacific Biodivers., vol. 10, no. 2, pp. 192-198, 2017.

Supriadi, 2003. Produktivitas Lamun Enhalus acoroides (LINN.F) Royle dan Thalassia hemprichii (EHRENB.) Ascherson di Pulau Barang Lompo Makassar. Skripsi. Institut Pertanian Bogor.

Utami, D.K. 2012. Studi Bioekologi Habitat Siput Gonggong (Strombus turturella) Di Desa Bakit, Teluk Klabat, Kabupaten Bangka Barat, Provinsi Kepulauan Bangka Belitung. Skripsi. Institut Pertanian Bogor.

Viruly, L. 2011. Pemanfaatan Siput Laut Gonggong (Strombus canarium) Asal Pulau Bintan-Kepulauan Riau Menjadi Seasoning Alami. Skripsi. Institut Pertanian Bogor.

Wicaksono, S.G., Widianingsih., Hartati, Sri T. 2012. Struktur vegetasi dan kerapatan jenis lamun di perairan kepulauan karimunjawa kabupaten jepara. Jiurnal Oof Marine Research, 1(2), 1-7. 
Will, M., Kandel, A. W., Kyriacou, K., Conard, N. J. 2016. An evolutionary perspective on coastal adaptations by modern humans during the Middle Stone Age of Africa. Quaternary International, 404, 6886. https://doi.org/10.1016/j.
Zabarun, A. 2016. Hubungan panjang berat, faktor kondisi dan rasio berat daging Kerang Pasir (Modiolus modulaides) di perairan Bungkutoko Kota Kendari. Jurnal Manajemen Sumber Daya Perairan, 2(1),21-32. 